\title{
Interorganizational Learning: A Bibliometric Review and Research Agenda
}

\author{
Dr. Amitabh Anand* \\ SKEMA Business School, Université Côte d'Azur, GREDEG, France \\ Dr. Louise Brøns Kringelum \\ Department of Business and Management, Aalborg University, Denmark \\ Dr. Charlotte Øland Madsen \\ Department of Business and Management, Aalborg University, Denmark \\ Ms. Louisa Selivanovskikh \\ Graduate School of Management, St. Petersburg State University, Russia \\ *Corresponding Author
}

Purpose: Scholarly interest in interorganizational learning (IOL) has spiked in the last decade due to its potential to absorb, transfer and create valuable knowledge for enhanced innovative performance and sustained competitive advantage. However, only a handful of review studies exists on the topic. The evolution of IOL has not been studied explicitly and there is a lack of understanding of the field trends. In order to fill this gap, we comprehensively review the literature on IOL and map its evolution and trends using bibliometric techniques. In particular, we use visualization of science mapping (VOS) freeware to systematize our findings and interpret the results.

Design/methodology/approach: We synthesize the findings using 'evaluative bibliometric techniques' to identify the quality and quantity indicators of the IOL research and use 'relational bibliometric techniques' to determine the structural indicators of the IOL field such as the intellectual foundations and emerging research themes of IOL research.

Findings: Through an analysis of 208 journal publications obtained from the Scopus database, we determine the leading authors, countries, highly cited papers and their contributions to the IOL literature. By identifying the key hotspots, intellectual foundations and emerging trends of IOL, we provide promising avenues in IOL research.

Originality/value: To the best of our knowledge, this study is the first to systematically review the IOL literature and provide future research directions 


\subsection{Introduction}

In recent years, the constant struggle for business survival, severe market competition and presence of disruptive innovations has pushed organizations to their limits, forcing them to operate in highly ambiguous, complex and uncertain environments (Bouncken and Barwinski, 2020; Vecchiato, 2017). In this context, companies are striving to become more innovative in the ways products and services are developed and customer relations are built, therefore, creating new valuable knowledge and engaging in activities that help facilitate individual and organizational learning (PopovaNowak and Cseh, 2015). The learning aspect of firm-level practices and initiatives is especially important as it improves work processes and innovation (Sheng and Chien, 2016; Tolsby, 2018), provides new market insights (Raj and Srivastava, 2016; Surdu et al. 2018) and enhances the overall performance of organizations in dynamic contexts and settings (Bendig et al. 2018; Camps et al. 2016). Learning occurs in organizations through individual and collective interactions at various levels (group, organizational and interorganizational) (Andreou et al. 2016; PopovaNowak and Cseh, 2015), through collaboration with other firms and adoption of best practices (Larsson et al. 1998; Mariotti, 2012).

Scholars and practitioners generally focus on organizational learning and its connection to enhanced firm performance (Eiriz et al. 2017; Huang and Chu, 2010). In recent years though, more attention has been given to learning between organizations, that is interorganizational learning (IOL), and its role in knowledge creation and transfer between and across organizations (Kohtamäki and Partanen, 2016; Liu, 2012). As companies are becoming more interconnected through strategic alliances, partnerships and collaborations (Engeström and Kerosuo, 2007), the increased interest in this phenomenon has encouraged scholars to continuously investigate the underlying mechanisms and processes of IOL (Easterby-Smith et al. 2008; Mariotti, 2012; Rajala, 2018). 


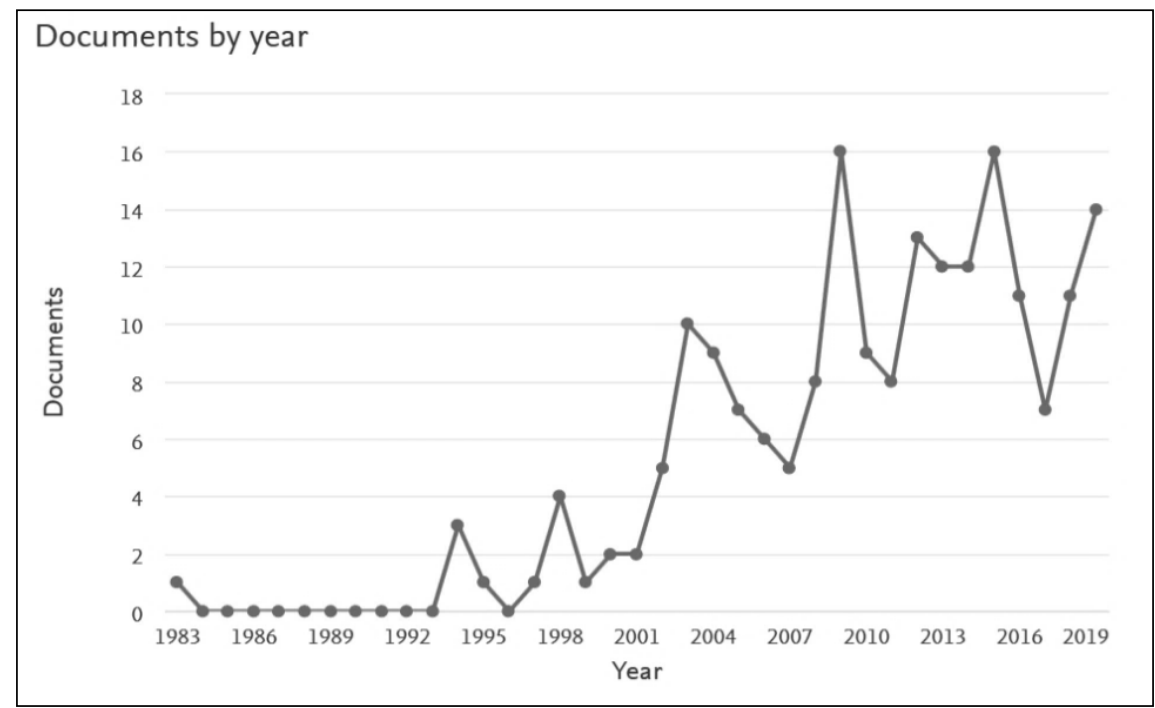

Figure 1: Sample distribution of publications on IOL between 1983 to 2018

The growing interest in IOL is evident in academic literature and the distribution of publications over the last decade (2009-2019). Using keywords such as "interorganizational learning" in the Scopus database we found a dispersed growth rate in the number of publications (i.e. conference papers, journal articles, book chapters and editorials) from 1983 to 2018 (Figure 1). The studies overwhelmingly represented the domains of business, management, accounting and social sciences.

IOL has indeed become an important research area (Easterby-Smith et al. 2008; Rajala, 2018), with it gaining prominence in a variety of disciplines, including innovation, knowledge management and organization studies in general (Eiriz et al. 2017; Ring and Van de Ven, 1994). However, the field also faces several challenges. These challenges include a lack of consensus amongst researchers as to which factors affect IOL activities at different levels (Rajala, 2018), no clear, explicit definition and limited knowledge of how IOL unfolds in different settings (Mariotti, 2012). While the IOL field continues to grow, the need for a more productive discourse and further advancement of the field is required. Previous IOL reviews have not been conducted comprehensively but rather focused on narrow phenomena and limited to specific contexts, for 
example IOL and its connection to performance (Mariotti, 2012; Rajala, 2018). In contrast, this study aims to review the IOL literature and identify its evolution and emerging themes by using a transparent, reproducible and systematic review methodology that allows for further similar explorations.

\subsection{Background and Research Questions}

As a discipline progresses and reaches maturity, "an interest in knowing the 'state of the art' of the literature tends to grow amongst its researchers" (Portugal Ferreira, 2011, pg.357). Scholars constantly look for new information to upgrade the knowledge base and discover new research avenues that open-up debates on specific topics of interest. Hence, it is critical to conduct periodic reviews of existing research fields to identify key contributions and construct substantiated arguments about the field's development (Denyer and Tranfield, 2006). Literature reviews can help assess the relevant intellectual territory for further knowledge development (Tranfield et al. 2003); they also provide early stage researchers with insights into important authors, institutions, countries, key themes and works (Benckendorff and Zehrer, 2013; Jiang et al. 2017; Serenko and Dumay, 2015). Nevertheless, no studies to date have shown the intellectual foundations and trends of IOL using bibliometrics, suggesting the need for a comprehensive review.

While a few scholars have attempted to review IOL and IOL-related fields, they are limited in scope and clarity. For instance, Mariotti (2012) develops a framework to understand the key underlying processes of IOL: collaboration, learning knowledge sharing and creation of interorganizational knowledge. Rajala (2018) focuses on how IOL can enhance performance and under what conditions IOL is effective in the context of supply chains. We believe these reviews have limitations in providing a rationale for the choices related to methodology and selection of publications, in particular the type of scientific works adopted for the analysis (e.g. articles, book 
chapters, conference papers, or editorials). With this in mind, we set the goal of exploring and systematizing extant IOL literature using transparent and systematic bibliometric methods.

While there are a myriad of techniques for analyzing literature such as narratives, structured reviews, meta-analysis, etc., bibliometric techniques combined with science mapping software has the potential to categorize, conceptualize and uncover trends compared to other traditional methods of literature review (Connaway and Powell, 2010; Garg and Tripathy, 2017; Galvagno, 2017; Walsh and Renaud, 2017; Vogel and Güttel, 2013). The methodological rigor of bibliometrics are believed to be strong, and the insights it offers are fully quantifiable, and not skewed by researchers' cognitive prejudices (Mariani and Borghi, 2019; Galvango, 2017). In this study, we adopt two broad bibliometric techniques, namely: 1) evaluative techniques (Gaviria-Marin et al. 2018); and, 2) relational techniques (Benckendorff and Zehrer, 2013; Koseoglu, 2016). The combination of these two techniques help to identify qualitative, quantitative and structural growth in a specific research field (Gaviria-Marin et al. 2019).

For instance, to measure productivity outcomes the evaluative technique use quantity indicators (e.g. leading journal publications, leading authors on the topic, leading country publications, leading authors' in citations, etc.) and quality indicators (e.g. journal impact metrics such as citescore, source normalized per index (SNIP), scientific journal ranking (SJR) etc.). In comparison, the relational technique provides structural indicators that create and elicit relationships between various actors/themes in a specific research field. This includes measuring and mapping linkages between different journals, authors, keywords, references, using co-citation, co-authorship, coword/keyword occurrences and bibliographic coupling (see e.g. Borner et al. 2003; Baraba'si et al. 2002; Durieux and Gevenois, 2010; Cobo et al. 2011; Gaviria-Marin et al. 2019). The relational technique further helps to identify theoretical foundations (Zupic and Cater, 2015) and emerging trends (Walsh and Renaud, 2017). Consequently, to guide our research process and identify 
quantitative and structural indicators in IOL literature, we introduce the following research questions:

RQ1. Which countries lead in the number of works published in the field of IOL?

RQ2. Who are the leading authors in IOL literature?

RQ3. Which are the leading institutions/affiliations in IOL literature?

RQ4. What are the most cited publications of IOL and their contribution?

RQ5. What are the important keywords and themes used to study IOL?

RQ6. What are the intellectual foundations/evolutions of IOL?

RQ7. What are emerging research themes/trends in IOL?

\subsection{Methodology}

In this section, we present a structured, transparent and reproducible methodology for the purpose of generating new valuable and original research outputs (Aguinis et al. 2018; Torchia and Calabrò, 2011). Thus, to ensure the necessary scientific rigor, we follow the five-step process - suggested by Tranfield et al. (2003) - for performing a systematic literature review and analysis.

First: We conducted comprehensive research (including, the identification of keywords, construction of the search strings and selection of the databases, among other processes) according to the guidelines of Cerchione and Esposito (2016). We selected Elsevier's 'Scopus' database (Tran and Aytac, 2016) to extract relevant publications from various indexed journals. In comparison to other databases, such as Web of Science (WoS) and Google Scholar, Scopus is more widely used (Harzing and Alakangas, 2016), potentially due its robustness, convenient interface as well as the presence of different sorting, ranking and refining features. Consequently, we performed a keyword search to extract publications from this database for further analysis (Table 1). To ensure comprehensibility, we considered different spelling options in our search of 'organiz/sation' as the 
spelling may differ from one study/journal to another. Out of 208 hits we found 189 papers that use a ' $z$ ' spelling (between 1994 to 2019). The data was extracted in September 2019 and, as the Scopus database gets updated on a regular basis, the number will likely differ in the future search. We only included journal articles (excluded editorials, conference papers and book chapters) due to their merit in the scientific community and methodological rigour and standards (Thyer, 2008).

\begin{tabular}{|l|l|}
\hline Keyword Protocol & $\begin{array}{l}\text { Publications } \\
\text { Extracted }\end{array}$ \\
\hline TITLE-ABS-KEY ("Interorganizational Learning" OR "Inter-organizational & 208 \\
Learning" OR "Interorganisational Learning" OR "Inter-organisational Learning") & \\
AND (LIMIT-TO (DOCTYPE, "ar") OR LIMIT-TO (DOCTYPE, "re" ) OR LIMIT- & \\
TO (DOCTYPE, "ip") ) AND (LIMIT-TO (SRCTYPE, "j" ) ) & \\
\hline
\end{tabular}

Table 1: Keyword search string

Second: To study the trends in literature (based on the obtained 208 publications), we adopted bibliometric methods. Such methods are often combined with science mapping tools and techniques to visualize discipline structure (Walsh and Renaud, 2017; Zupic and Cater, 2015) and study clusters (Sedighi and Jalalimanesh, 2014; Walsh and Renaud, 2017). They include, for example, qualitative and quantitative text analysis software such as VOS Viewer (Van Eck and Waltman, 2010), BibExcel (Cobo et al. 2011) and CoPalRed (Bailón-Moreno et al. 2006). In this paper, we used Van Eck and Waltman's (2010) visualization software VOS Viewer, which maps the bibliography and citation trends represented through clusters, tables and maps (Jiang et al. 2017; Walsh and Renaud, 2017). Over the last decade (2009-2019), VOS viewer has been adopted and widely applied by scholars, with different literature reviews published in top ranked journals (e.g. Apriliyanti and Alon, 2017; Gaviria-Marin et al. 2018). In the figure below, we present a flow chart of the bibliometric mapping used in the VOS viewer application (Figure 2). 

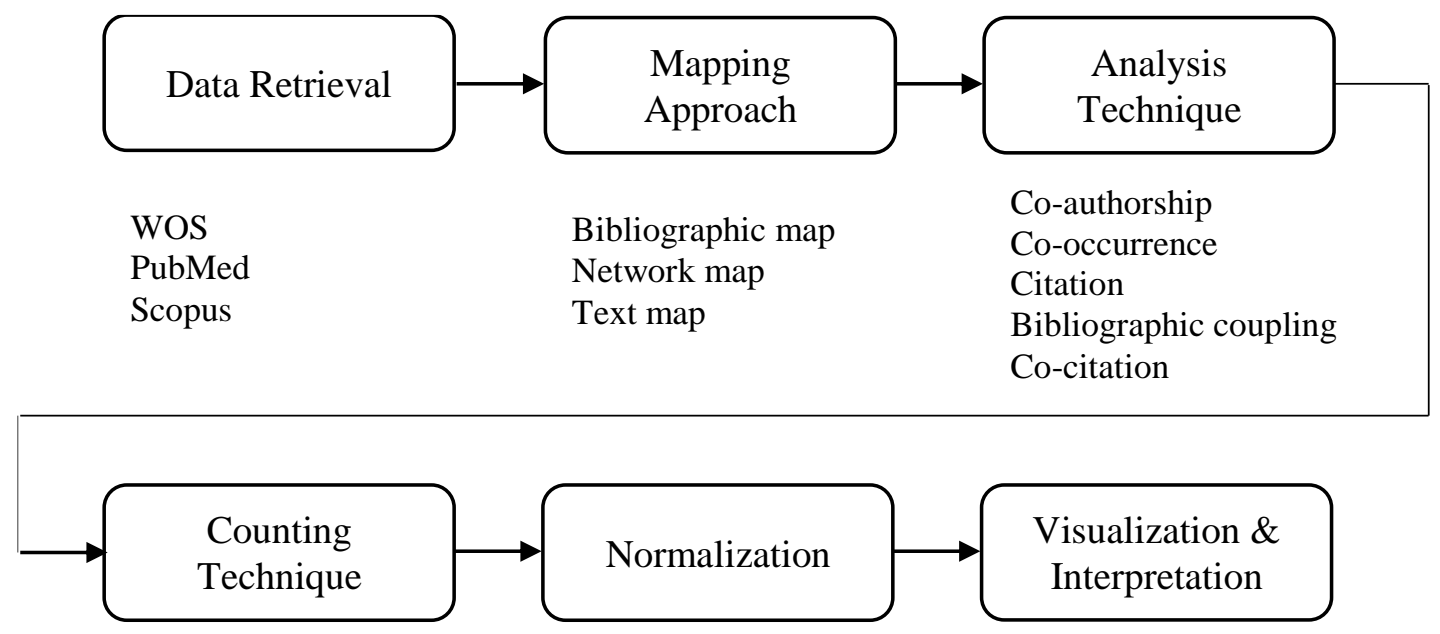
Fractional counting
Full counting
Association strength
Fictionalization
Lin/Log modularity
Network visualization
Density visualization

Figure 2: VOS-Viewer flow-chart explaining the steps involved in analysis (Source: Authors)

Third: To answer our research questions, we adopted two bibliometric techniques, namely: 1) evaluative techniques (Gaviria-Marin et al. 2018); and, 2) relational techniques (Benckendorff and Zehrer, 2013; Koseoglu, 2016). We used Scopus metrics as an evaluative technique. The Scopus database provides distinctive features to classify publications in a given field based on the following metrics 1) leading citations, 2) leading authors, 3) leading institutions, 4) leading countries and 5) leading journals (Gasparyan et al. 2018; James et al. 2018; Mering, 2017). Next, we used the following relational techniques: 1) to identify the important keywords, that help in exploring research hotspots/themes (Liao et al. 2018), we performed a co-occurrence of keyword analysis (e.g. author/index keywords) and a content analysis of text data (e.g. abstracts) using VOS viewer. 2) to study the field's intellectual foundation/evolution we adopted co-citation analysis of references (e.g. Walsh and Renaud, 2017) using VOS viewer and, 3) to identify the emerging trends we used documentation of the timeline series (e.g. Gurzki and Woisetschläger's 2017). 
Fourth: To include central publications for further analysis from the 'co-citation analysis of references' we singled out the ten most highly co-cited publications as a foundation for exploring the evolution of the IOL field (cf. Belussi et al. 2019). Further, to identify the emerging trends, we followed Gurzki and Woisetschlägers (2017) suggestion concerning the inclusion / exclusion of publications. The authors argue that a threshold point can be chosen as a proxy in a bibliometric dataset where the publications were seen to 'spike' in a given time period. This produces a broad sample to investigate recent developments in the field. From Figure 3, we can see that the number of publications significantly increased in 2009 , indicating the growing academic interest in IOL research. Focusing on the papers published in 2009-2019, we got a dataset of 143 publications (Figure 3).

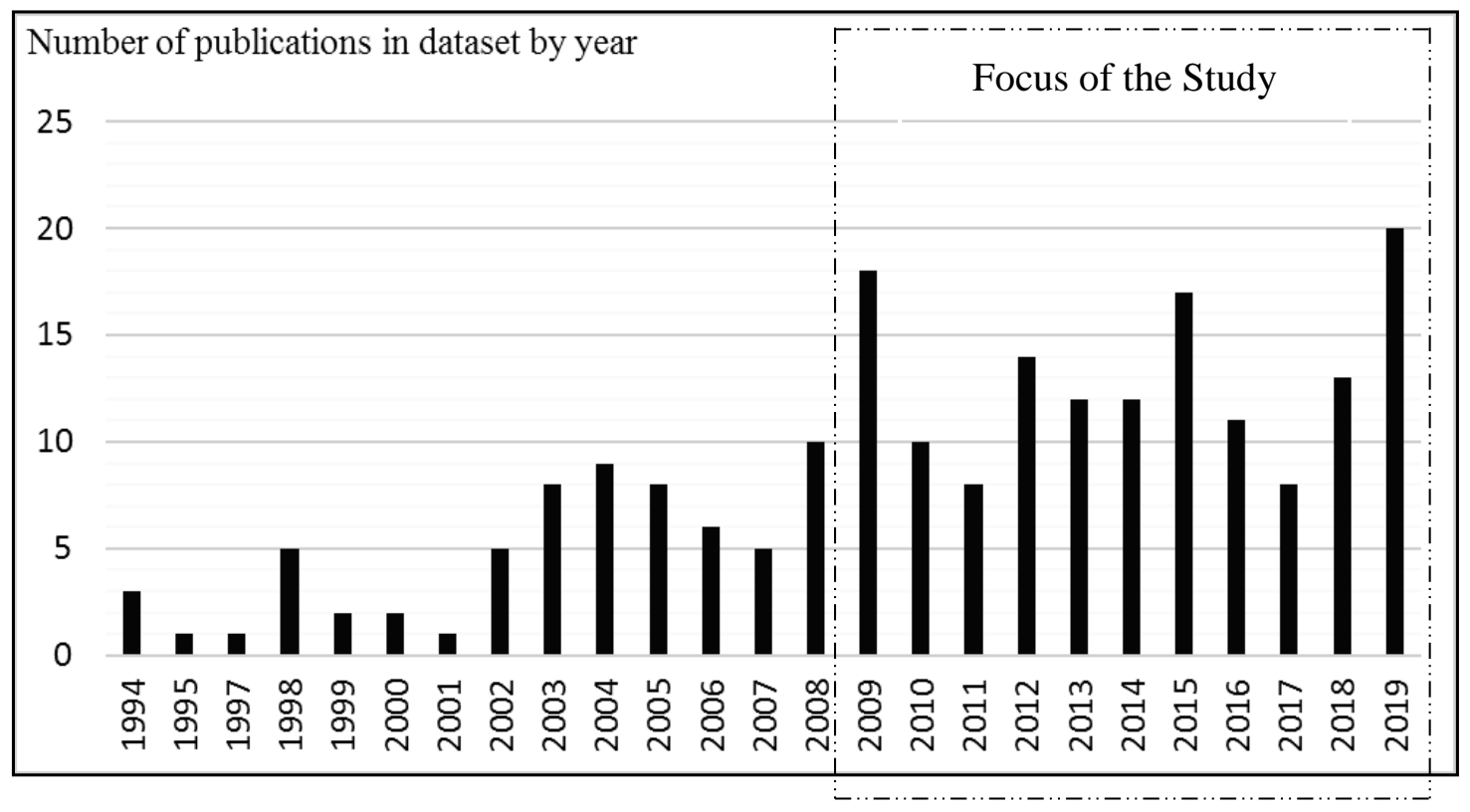

Figure 3: Number of publications in the dataset per year

For further analysis, we adopted qualitative descriptive coding following the guidelines of Cerchione and Esposito (2016). In particular, we read the abstracts of each paper as they help to "consolidate ideas and opinions regarding the research" (Salager-Meyer, 1990: 367) and "serve as a key to understanding fully the argument of the original article" (Swales, 1990: 179). Two of the 
authors independently studied the abstracts and collocated their notes while two other authors checked again for consistency. Based on the content of abstracts, 124 out of 143 publications were selected and coded. The content of abstract was coded based on: a) the context in which IOL is addressed; b) theoretical framework/lens (whether IOL has been explored from any theoretical perspective in general); c) the antecedents of IOL; d) consequences and potential outcomes; e) methodology applied in exploring IOL.

Fifth: We undertook systematic reviews concerned with synthesis (Snilstveit et al. 2012; Thomas et al. 2012) to show our findings from the above four steps. Synthesis is a systematic approach for combining, integrating and synthesizing varied literature through narratives and summary (SchickMakaroff et al. 2016). Thus, the chosen publications were synthesized based on common parameters using a table matrix: topical and methodological similarities, context, variables and differences, antecedents, theories, and outcomes. The results were used to explore the emerging themes and explicate future research agendas for the IOL field.

\subsection{Findings}

\subsection{Using Scopus Metrics as an Evaluative Technique}

\section{RQ1. Which countries lead in the number of works published in the field of IOL?}

A publication from a country is defined as an article in which at least one author is affiliated to an institution located in that country (this is identified by the authors' contact information) (LópezIllescas et al. 2009). Knowing the countries from which publications originate may help researchers focus on the geographical representation of concepts and contexts.

In Figure 4, we set the threshold to a minimum of five publications to identify the largest and smallest number of publications on IOL by country. In terms of non-Western countries, Brazil is 
associated with five publications, whereas Taiwan leads with nine publications. In comparison, most publications are found in the United States (US) (53), United Kingdom (UK) (32) and Finland (19). These statistics suggest that there is an uneven distribution of IOL literature and only a handful of countries pioneer in IOL studies. Although Europe and the US take leading positions in the number of publications on IOL, Vogel et al. (2017) argue that the language advantage of USand UK-native scholars makes it easier for them to publish research publications in highly ranked journals (however, we should note here that scholars working at universities associated with these English-speaking countries are not necessarily native to those countries). Among the papers with high citation counts are papers authored by prominent US researchers, including Lane and Lubatkin (1998) with 2499 citations and Larsson et al. (1998) with 566 citations. From the UK, Knight (2002) has 120 citations and Morrison et al. (2004) has 103 citations; and in Finland, Engestrom and Kerosuo (2007) have 84 citations and Schildt et al. (2012) have 71 citations.

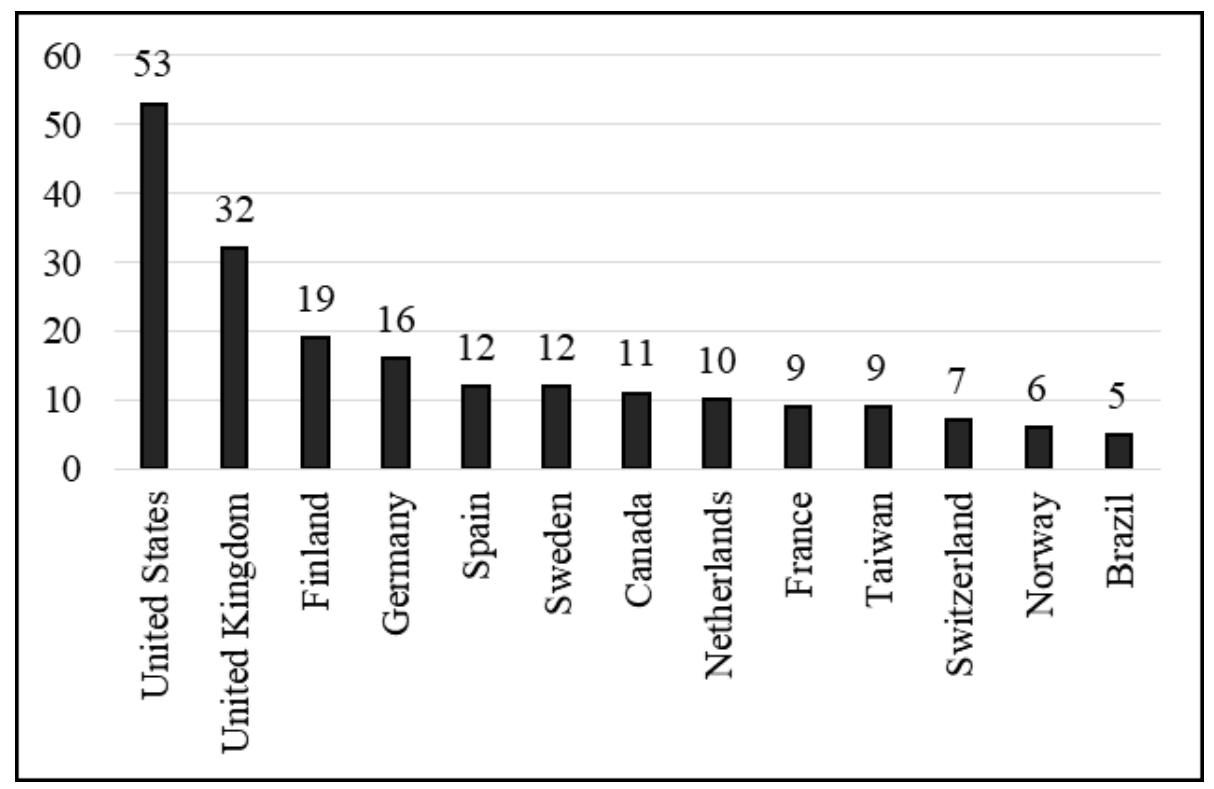

Figure 4: Distribution of publications by leading countries 


\section{RQ2. Who are the leading authors in IOL literature?}

Authors leading in the number of published papers on a topic are recognised as active researchers in that particular discipline (Kolle et al. 2017; Kolle et al. 2015). In Figure 5, the leading author's publication is based on the affiliation or contribution to an article but does not denote the position of the scholar in the author list.

The IOL literature is influenced by R. Bouncken from the University of Bayreuth, Germany - she published four papers between 2015 and 2019 (inter alia, Bouncken et al. 2015; Bouncken et al. 2016; Fredrich et al. 2019), becoming the most active recent researcher in the field - followed by J. Hartley from the Open University of the UK, M. Holmqvist from Stockholm University, Sweden, and R. Smeds from Helsinki University of Technology, Finland, each with four articles published within the periods of 2002-2018, 2003-2009 and 2003-2013 (accordingly) (inter alia, Hartley and Rashman, 2018; Holmqvist 2004; Smeds and Alvesalo, 2003). The overview of leading authors and affiliations indicates that European authors are most actively engaged in IOL research suggesting their dominance and contribution to IOL literature.

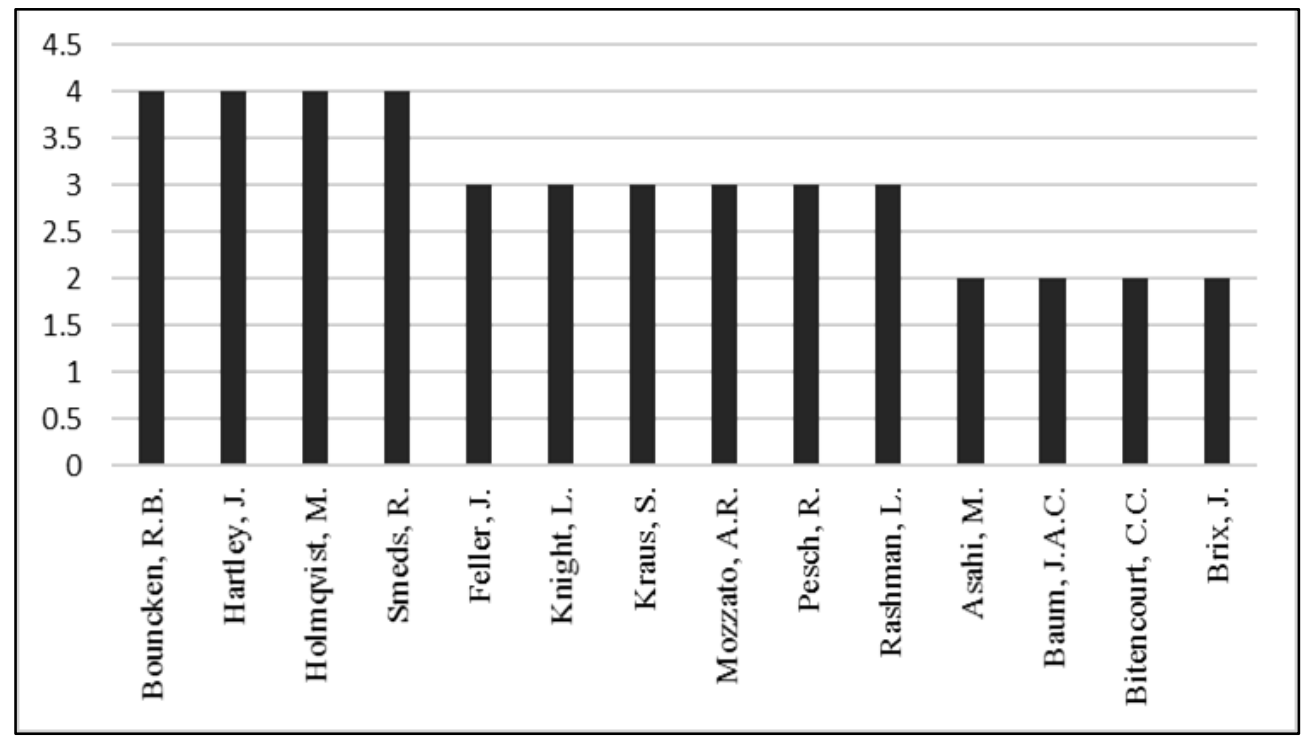

Figure 5: Distribution of publications by leading authors 


\section{RQ3. Which are the leading institutions/affiliations in IOL literature?}

Huang (2012) and Cancino et al. (2017) suggest that a university's or institution's capability to progress in a particular research field depends on the number of publications it produces and the H-index ranking that it holds. However, the number of publications in a peer-reviewed journal also gives researchers an overview of the most productive and influential universities in a discipline. From Figure 6, Europe's Aalto University leads in the number of publications on IOL. Although the US produces the largest amount of papers, no institution other than Yale University has published more than three scientific papers on the topic.

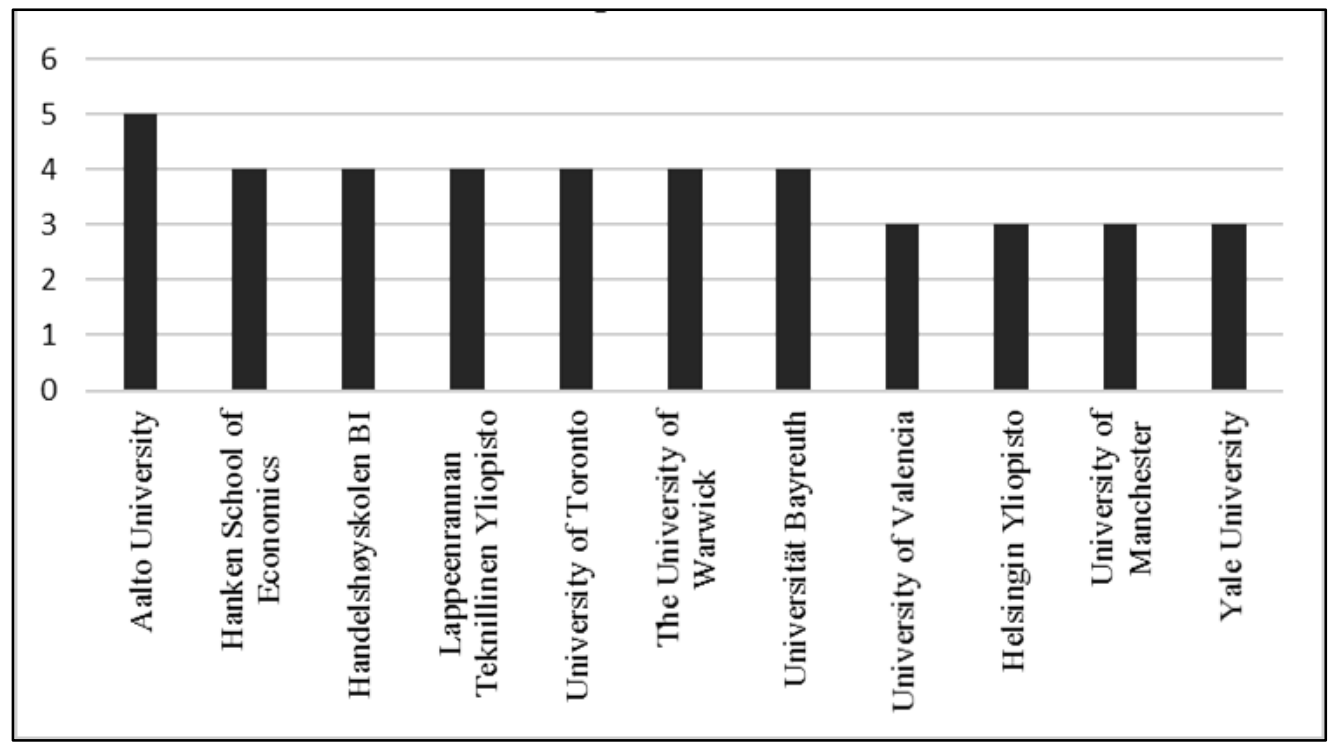

Figure 6: Distribution of publications by leading institutes

\section{RQ4. What are the most cited publications of IOL and their contribution?}

Serenko and Dumay (2015) suggest that highly cited publications are well-written and cover "hot" topics in a given discipline. In Table 2, we show the top ten highly cited papers obtained from the Scopus database, the journals they were published in and their citation count 


\begin{tabular}{|l|l|l|l|l|}
\hline Rank & Authors & Year & Source title & Cited by \\
\hline 1 & Lane and Lubatkin & 1998 & Strategic Management Journal & 2426 \\
\hline 2 & Larsson et al. & 1998 & Organization Science & 549 \\
\hline 3 & Baum and Ingram & 1998 & Management Science & 381 \\
\hline 4 & Holmqvist & 2004 & Organization Science & 334 \\
\hline 5 & Scott & 2000 & Journal of Management Information Systems & 191 \\
\hline 6 & Schildt et al. & 2005 & Entrepreneurship: Theory and Practice & 185 \\
\hline 7 & Holmqvist & 2003 & Organization Studies & 156 \\
\hline 8 & Schilke and Goerzen & 2010 & Journal of Management & 151 \\
\hline 9 & Levinson and Asahi & 1995 & Organizational Dynamics & 141 \\
\hline 10 & Cheung et al. & 2010 & Journal of Operations Management & 131 \\
\hline
\end{tabular}

Table 2: Distribution of highly cited publications in IOL

Naturally, such citation counts may represent a bias based on the time lag of peer-reviewed publication to gain prominence and create research impact. However, the aforementioned publications are regarded as highly influential and have helped build the foundation and further develop the IOL field. The context of each article varies. For instance, Larsson et al. (1998) emphasise the importance of formal collaborations, such as joint ventures, strategic alliances and licensing agreements in IOL. They suggest that IOL is contingent upon the "receptivity and transparency interactions" between organizational actors; these generate greater synergy and foster learning. Similarly, Lane and Lubatkin (1998) emphasise the role of an actor's characteristics in actively and passively engaging in IOL. Further, they based this on the theory of relative absorptive capacity, which can influence interactive learning in an interorganizational setting. Baum and Ingram (1998) argue that organizational activities such as the interaction among individuals through knowledge acquisition and information sharing reduce an organization's risk of failure in IOL.

Scott (2000) realizes that adoption of information technology in IOL can help firms to cope with the complexity of new products and the capital intensity in the disk drive industry. However, learning is most effective when it is based on trust. Holmqvist (2003; 2004) insists that organizational learning literature needs cross infusion of intra-/inter-organizational learning 
processes. Intraorganizational learning processes favour exploitation, while IOL processes favour exploration. Similarly, Schildt et al. (2005) use explorative and exploitative learning in entrepreneurial ventures and suggest that, in the process of learning new knowledge, corporate ventures are more strongly linked to exploratory learning. Levinson and Asahi (1995: 50) find that learning in the setting of strategic alliances can be institutionalized though "reforming the behavior of the alliance". Schilke and Goerzen (2010) conceptualize IOL as a dimension of alliance management capability and develop a measure for IOL in alliance networks. Cheung et al. (2010) highlight how IOL can create customer value.

\subsection{Using Bibliometric Relational Techniques}

\section{RQ5. What are the keywords and themes used to study IOL?}

The research 'hotspots' in a discipline can be found in keywords. An article's keywords are distinct because they represent what the authors consider to be the most important words in their paper and can potentially detect trending research topics in different time periods (Pesta et al. 2018). Based on the keywords extracted from the papers, VOS viewer creates a co-occurrence network in a twodimensional map (Walsh and Renaud, 2017) (Figures 7 and 8).

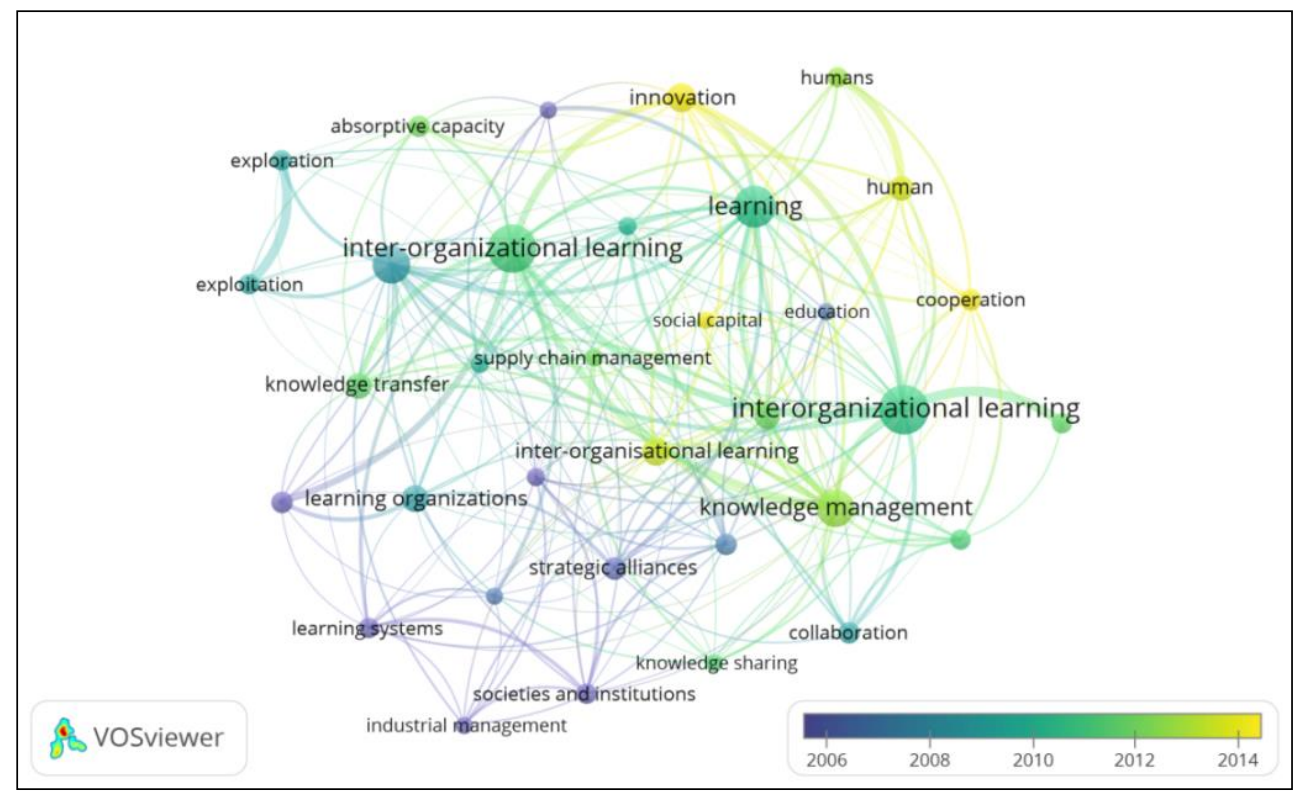


Figure 7: Important keywords appearing in IOL literature

Walter and Ribiere (2013) suggest that, by visualizing a map based on keyword relations, a general interpretation can be made on the concepts that are strongly semantically related. This visualization technique illustrates a global representation of the concepts and their relationships. Following the advice of Chen and Xiao (2016), publication keywords have been widely utilized to reveal the knowledge structure of research domains. Based on our analysis, IOL literature seems to be 'growing' around the disciplines of knowledge management, knowledge transfer and knowledge sharing. By observing the map, the following themes are identified: 1) the role of absorptive capacity theory in IOL; 2) the enabling conditions under which IOL is effective; 3) the impact of IOL on society and institutions; 4) the mechanisms of IOL in strategic alliances 5) the role of social capital, trust and capability in IOL; 6) how managing and sharing of knowledge between individuals and organizations can facilitate IOL; 7) the role of IOL in supply chain networks; and, 8) the impact of IOL on both individual and organization innovation performance.

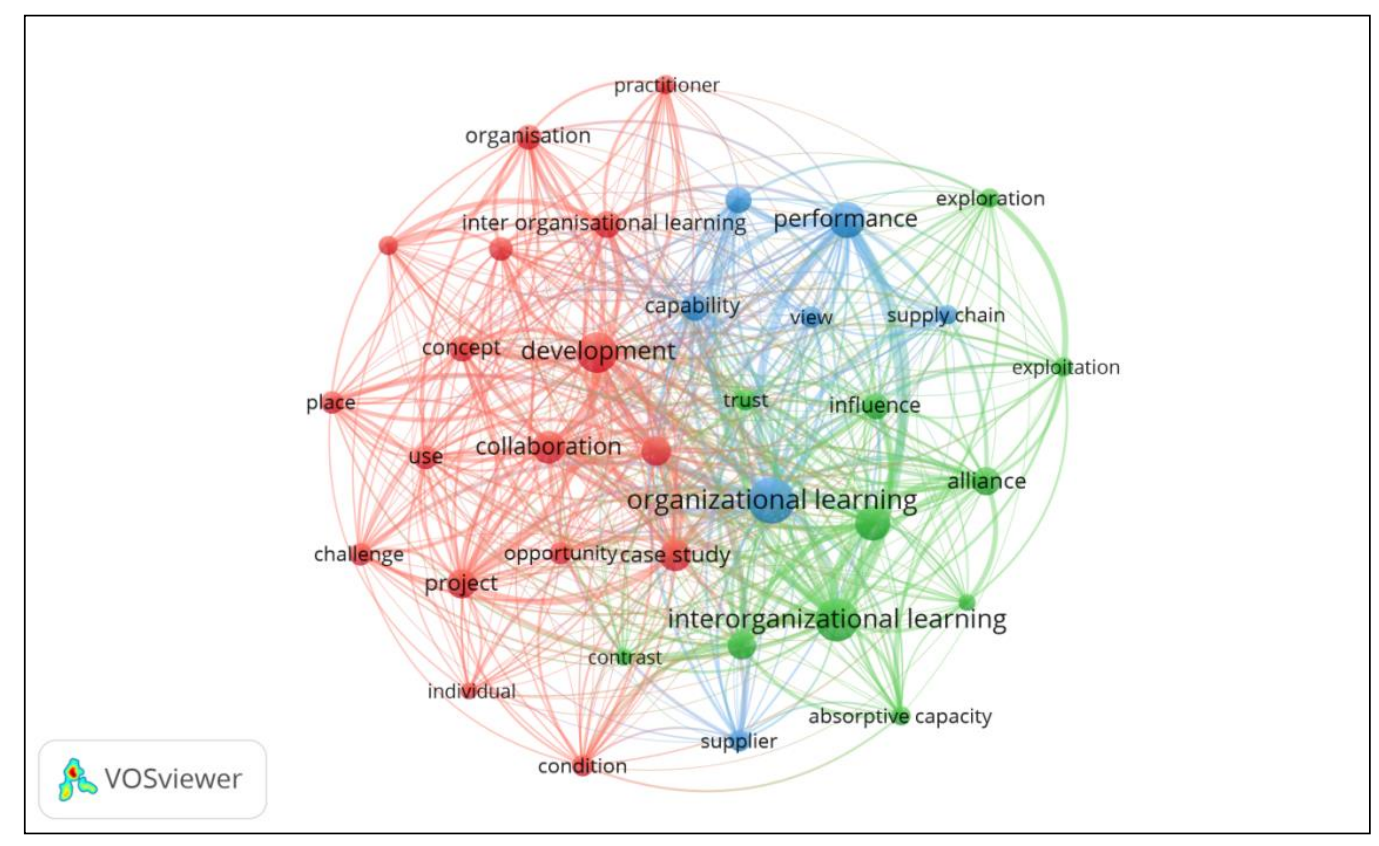

Figure 8: Important terms appearing from the abstracts in IOL Literature 


\section{RQ6. What are the theoretical/intellectual foundations of IOL?}

According to Walsh and Renaud (2017), in order to identify the foundations, theoretical pillars, and explore the existing relationships between authors, co-citation analysis of reference (CCA-R) should be adopted as the key bibliometric technique. In CCA-R, co-citation frequencies represent the proximities of two references (e.g. Raghuram et al. 2010; Renaud et al. 2016; Walsh and Renaud, 2017) that share the same reference and concepts emerging over time (Walter and Ribiere, 2013). This study identifies over 6,000 citations. Following the suggestions of Leung et al. (2019) and Walsh and Renaud (2017) and the recommendations provided in the VOS viewer manual, we establish a cut-off point (the references that have been cited at least five times) to select the most influential papers and seminal works. Thus, ten citations are selected for further analysis (Table 3).

\begin{tabular}{|l|l|c|l|}
\hline No & Authors & Year & Journal \\
\hline 1 & Levitt and March & 1988 & Annual Review of Sociology \\
\hline 2 & Cohen and Levinthal & 1990 & Administrative Science Quarterly \\
\hline 3 & Hamel & 1991 & Strategic Management Journal \\
\hline 4 & Huber & 1991 & Organization Science \\
\hline 5 & March & 1991 & Organization Science \\
\hline 6 & Nonaka & 1994 & Organization Science \\
\hline 7 & Powell et al. & 1996 & Administrative Science Quarterly \\
\hline 8 & Lane and Lubatkin & 1998 & Strategic Management Journal \\
\hline 9 & Larsson et al. & 1998 & Organization Science \\
\hline 10 & Crossan et al. & 1999 & Academy of Management Review \\
\hline
\end{tabular}

Table 3: Top ten seminal publications found from CCA-R bibliometric method

To better understand and provide a strong link to the evolution of IOL, we decided to explore the publications from highly cited articles from Table 2 and Table 3 . After carefully analyzing the 18 publications, we chose ten - the saturation point - that, in our opinion, best reflect the development of the IOL field: Levitt and March (1988), Cohen and Levinthal (1990), Hamel (1991), March (1991), Nonaka (1994), Levinson and Asahi (1995), Powell et al. (1996), Lane and Lubatkin (1998), Baum and Ingram (1998), and Holmqvist (2003). Figure 9 depicts the evolution of IOL research based on the 'expanded' time period (1998-2003) analysis of these ten highly influential, 
seminal papers published. Needless to say, the selected scientific works we analysed formed a strong foundation and solid base for contemporary discourse on organizational learning during these fifteen years.

For instance, in the beginning scholars focused on exploring, understanding and revealing the nature of the organizational learning phenomenon (rather than IOL as a phenomenon in its own right). Authors shed light on what organizational learning essentially was (its underlying mechanisms and processes, necessary 'inputs' and outcomes, firm-level consequences, for instance), why and how organizations engaged in particular learning activities and what factors facilitated/hindered a firm's ability to absorb and utilize valuable knowledge, gain relevant experience for certain competitive advantage gains. 


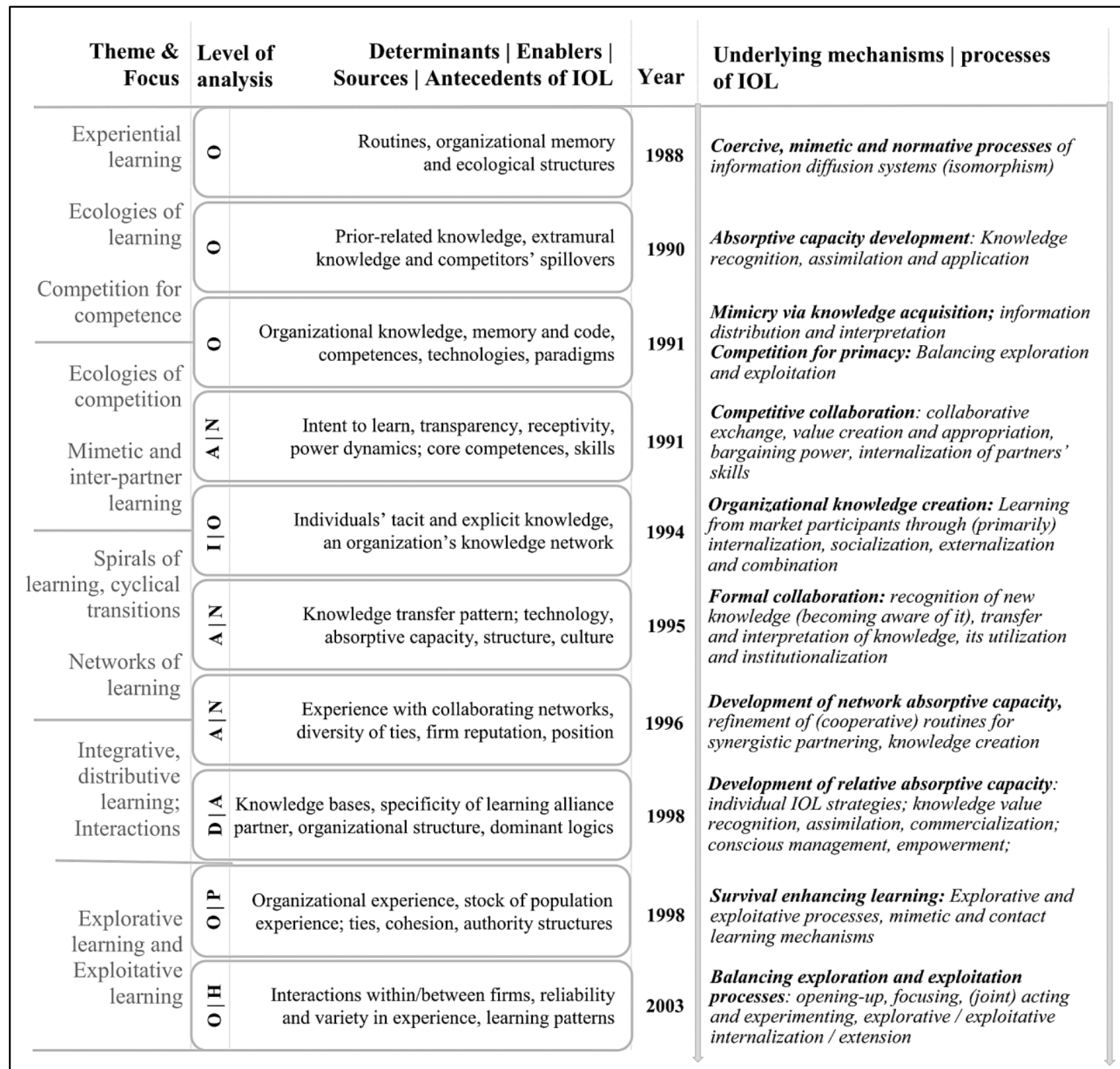

Note: I stands for Individual level, $\mathrm{O}=$ Organizational level, $\mathrm{D}=$ Dyadic level, $\mathrm{A}=$ Alliance level, $\mathrm{N}=\mathrm{Network}$ level; $\mathrm{H}=$ Hybrid level.

\section{Figure 9: The evolution of IOL literature}

Before the 'quantum leap' from intra- to inter-organizational level learning was made, management research mostly revolved around the individual, team and organizational levels as the primary units of analysis (focusing, inter alia, on core skills and competences, individual and collective knowledge, firm-level routines and encompassing value-creating disciplines). In these studies, the attempts to extend the theory to an interorganizational level were made by looking at the individual 
organization as an entity that interacts with and learns from the external environment. Other firms - the partners and competitors of the organization under investigation - were considered part of this highly competitive hostile environment. Therefore, the groundwork for an IOL theory was created based on research on experiential learning and the ecology of learning organizations (Cohen and Levinthal, 1990; Huber, 1991; Levitt and March 1988) as well as the ecology of competition, mimetic learning and inter-partner learning (Hamel, 1991; March, 1991; Nonaka, 1994).

On the other hand, different types of knowledge as well as organizational memory, knowledge networks within the organization, routines, competences and learning intentions have been considered the essential ingredients for the successful implementation of organizational learning processes at different levels, including the interorganizational one via mimicry, absorptive capacity development, organizational knowledge creation and competitive collaboration. Meanwhile, the actual 'prototype' frameworks for IOL were presented later, during the late $90 \mathrm{~s}$, with the introduction of more complex structures (based on the already defined and observed constructs) as part of the IOL process occurring at higher levels (that is, at alliance, network, hybrid and population levels). This focused on relative and network absorptive capacities (Lane and Lubatkin, 1998; Powell et al. 1996), learning patterns (Holmqvist, 2003), authority structures and organizational population experiences (Baum and Ingram, 1998), and hybrid interactions (Holmqvist, 2003), among others.

To conclude, a clear shift has been made from competition for primacy, mimicry and absorptive capacity development to collaborations, development of network absorptive capacity and explorative and exploitative capabilities as the underlying mechanisms of IOL. One can also witness the 'spiral of learning' within the IOL literature itself - from organizational learning to IOL and then from IOL back to organizational learning but with more focus as the knowledge 
gained from previous studies allows researchers to revisit and revaluate what is already known. This continuous cyclical process brings new insights (See Appendix-A).

\section{RQ7. What are emerging research themes/trends in IOL?}

To further identify the emerging themes and trends in IOL the abstract content of 124 publications on IOL from 2009-2019 were coded in a table format based on the following framework: 1) context/aim 2) theories 3) antecedents 4) consequences/outcomes 5) methodologies. The qualitative coding and mapping enabled us to explore recurring themes of IOL that touch upon the changing nature of IOL, how it is methodologically studied, the contextualization of IOL and the variation of theoretical perspectives included in the research field. This content analysis gave us five topics of interest to suggest for future studies to scholars within the field. They can be categorized into 1) IOL in and/or between organizations; 2) exploratory methods; 3) complex network structures; 4) strategic focus; 5) the role of innovation.

First (IOL in and/or between organizations): IOL research demonstrates a degree of conceptual ambiguity, where there is no clear distinction between the levels of analysis applied. As Holmqvist (2009) describes, IOL must be researched as a relatively complicated process resulting in a slower learning pace than is the case in intra-organizational learning processes. However, IOL is worth studying because it enables complicated learning, rather than exploitation or exploration in isolation. Complicated learning might be slow, but it is also beneficial to companies engaging in IOL. The potential differences in intra- and inter-organizational learning calls for attention in developing the concept of IOL and to focus empirical research. In a similar vein, Hallikas et al. (2009) calls for a definition of IOL to distinguish the concept from organizational learning and other types of learning, particularly in terms of how IOL differs when learning synergies are achieved from network interactions that would not otherwise have occurred. Content analysis suggests that there is increasing attention on addressing the risk of ambiguity and that researchers 
are defining the scope of OL and IOL more clearly. For this reason, the interlink between organizational learning and IOL is increasingly addressed in IOL research. This is found in Choi et al. (2019) as they explore both the absorptive learning capacity and the joint learning capacity among business partners. This provides a way of thinking about organizational learning and IOL as concepts that must be explored together and cannot be divided, which also entails that some level of ambiguity must exist between organizational learning and IOL. The research stream that focuses on the interplay of inter- and intra-organizational learning (Melo and Beck, 2015) appears to be growing and the theme of IOL in and/or between organizations continues to represent a central research theme to be explored further.

Second (Exploratory methods): Traditionally, IOL has been focused on providing conceptual developments and prescriptive guidelines for managers (Ameli and Kayes 2011; Castrillon et al. 2012; Halachmi and Woron, 2013; Hallikas et al. 2009; Manuj et al. 2014; Mozzato et al. 2015; Ruel et al. 2013). Content analysis shows that while many studies on IOL are conceptual, there is a growing tendency for research to adopt an empirical, experimental approach to studying the phenomenon in practice. While the focus on managerial implications persists, there appears to be more openness regarding the study of IOL using different methodologies in various contexts and settings. For instance, Sienkiewicz-Małyjurek et al. (2019) use desk research, participant observation and focus groups to explore IOL processes in the public safety management system affected by dynamic and uncertain operating conditions; while Leung et al. (2019) attends meetings, hosts workshops and conducts interviews to explore the learning practices of Industry Peer Network members. In addition, more studies using longitudinal data are also beginning to appear (Bouncken et al. 2015; Hartley and Rashman, 2018; Mutiganda, 2016; Schildt et al. 2012; Storbacka and Nenonen, 2015; Vasudeva et al. 2015; Wadhwa and Basu, 2013). Thus, further research is recommended to focus on the conceptual development of IOL with strong shared 
concepts and to apply these concepts in further quantitative and qualitative research, especially in longitudinal and in-depth case studies.

Third (Complex network structures): The content analysis shows that the conceptual and empirical studies of IOL in supply chains were focused on performance optimization and knowledge generation in dyadic or interfirm relationships (Hernández-Espallardo et al. 2010; Huang and Chu, 2010; Manuj et al. 2013; Ruel et al. 2013). Manuj et al. (2014) emphasize that the IOL concept can be used to further explore the complex processes of knowledge co-creation in supply chains. More recent publications highlight networks as a central level of analysis in IOL. Networks provide new contexts for learning (Peronard and Brix, 2019) as they can facilitate IOL and knowledge transfer (Broekel et al. 2014). Thus, IOL is explored within various forms of networks, for example, knowledge networks (Eiriz et al. 2017), horizontal networks (Gibb et al. 2017) and supplier networks (Kim, 2016). When regarding the network as a learning entity (Gibb et al. 2017), new premises for exploring IOL arise as the network encompasses both dyadic and network relations (Eiriz et al. 2017) that must all be considered in the process of exploring IOL. As emphasized in the section on RQ6, the level of analysis has been changing and will probably continue to do so to explore newer aspects of ecosystems (Andrade et al. 2019; Vesalainen et al. 2017). Moving from a focus on supply chains and the complex processes of knowledge co-creation to exploring other forms of networks with more complicated structures, and maybe even into ecosystems, calls for further research on how IOL unfolds and is affected in these new forms of collaboration.

Fourth (Strategic focus): The content analysis reveals a minor but continuous focus on the strategic considerations of initiating and managing IOL. This is specifically in regard to the creation and management of strategic alliances (Salmi and Torkkeli, 2010) and design of strategic networking practices (Benavides Espinosa, 2011; Cheung et al. 2010; Fang et al. 2010; Otto, 2012). 
However, the concept of strategic alliances in recent literature and the focus on either exploitation or exploration changes over time. In alignment with different forms of collaboration, the narrow scope of research on strategic alliances might simulate that of supply chain research in IOL research. As seen in the dichotomy of cooperative or competitive strategies between strategic networks, explicated by Wegner and Mozzato (2019), network learning provides a new context for exploring the strategic decisions in regard to IOL. In addition, the strategic choices regarding IOL and knowledge sharing appears to be especially interesting in small- and medium-sized firms (Bouncken et al. 2015) as their knowledge sharing processes can be challenged due to the position in the supply chain or network. Thus, further research on IOL-related strategic issues in networks and ecosystems provides an interesting new field of research.

Fifth (The role of innovation): The content analysis reflects that most studies address the expected causal relationship between IOL and innovative performance (c.f. Martínez-Noya and GarcíaCanal, 2016; Zhu et al. 2018). Often, innovation is connected to the fundamental organizational learning paradox of exploration and exploitation (Brix, 2019). Following the seminal paper of March (1991), this theme is not surprising, but what provides new areas of research is how the phenomenon of ambidexterity - a firm's ability to pursue exploitation and exploration simultaneously - is perceived as something that can be obtained structurally across different organizations as interactive or integrative inter-organizational ambidexterity (Brix, 2019). This emerging trend builds on existing research into exploration and exploitation, but adds ambidexterity to the previous focus as a concept that primarily exists at the organizational level and is influenced by the partners with whom small firms (for instance) decide to create an alliance with, as discussed by Hao and Feng (2018). The concept also considers the balance firms should create when acquiring new knowledge or technology through learning activities. This perspective on creating innovation through IOL requires a focus on trust building, as elaborated by Feller et al. 
(2013), who focus on knowledge transfer mechanisms in promoting IOL within research and development $(\mathrm{R} \& \mathrm{D})$ alliances. They find that competitors have the best possibilities of engaging in IOL R\&D, however, their research also identifies that issues of trust are of high importance. The importance of trust and other relational capabilities is increasingly explicated in IOL research (Peronard and Brix, 2019; Leung et al. 2019), however, the concept of co-opetition in IOL (e.g. Fredrich et al. 2019) is still novel in the field. The concept of innovation seems to be changing in regard to the level of analysis applied in IOL; this offers the potential to explore the innovation process of IOL as open innovation, as introduced by Bouncken et al. (2016) and Chatenier et al. (2009).

\subsection{Research Directions and Implications}

As illustrated throughout the seven research questions, multiple avenues for future directions and implications for future IOL research exist. In the following, we present four such promising future directions and implications:1) the growth of IOL literature, 2) the need for interdisciplinary and international collaboration in IOL literature, 3) the need for more critical and advanced reviews, 4) the need for more exploratory research methods.

The growth of IOL literature. IOL literature is progressing, with the number of publications since 2009 having doubled compared to previous years (e.g. between 1994 and 2008). This demonstrates the growing interest among field scholars. We also found that IOL is gaining popularity across different fields and domains, in multidisciplinary areas such as the social science and decision science domains (Table 1). The growing interest of scholars from different disciplines can be linked to the many theories in the social sciences that focus on the role of individual behaviour, collaboration and relationship dynamics between employees in an organization. Findings also suggest that recent studies lack frameworks to understand the various antecedents and 
consequences of IOL. This calls for future research to develop and test conceptual/theoretical models. For instance, frameworks can help understand and analyse how IOL differs in small, medium and large enterprises. This can further enhance scientific rigor and raise the standard for publishing more comprehensive studies.

The need for interdisciplinary and international collaboration in IOL literature. The IOL literature may exhibit signs of the 'Matthew effect', in which a small fraction of researchers or institutions produce the most work and attract a disproportionate number of citations (Serenko and Dumay, 2015). As seen in Figures 4, 5 and 6, evidence suggests that there is a strong need for more international collaborative research projects to analyse the IOL phenomenon in different emerging market contexts and settings (e.g. India, Indonesia, Mexico, Russia), as well as more cross-country analysis (e.g. investigating the processes of IOL in different country contexts, comparing one country and region to others or IOL from MNE, subsidiary context). This convergence of different perspectives may open new debates and bring new insights to IOL literature. These studies can increase the citation impact and stimulate multidisciplinary dialogue between scholars (Massaro et al. 2016). Thus, the future of IOL research relies on international scholarly collaboration and interdisciplinary perspectives and contributions.

The need for more critical and advanced reviews. The results of this paper may guide scholars towards producing impactful studies through critical and more advanced reviews. For instance, future research may encourage a debate among scholars to scrutinize the quality and operationalization of major concepts in IOL. Furthermore, this study also calls for scholars to employ more advanced text mining techniques, AI based tools and other software (e.g. biblioshiny, Gephi) to map results to complement, and potentially challenge, the findings of this paper. Scholars 
can also use journal specific bibliometric analysis (e.g. Gaviria-Marin et al. 2018) to study the trends in IOL literature. For instance, bibliometric data from the 208 dataset shows that The Learning Organization journal has been the leading outlet for IOL-related studies (Figure 10). Thus, as a dedicated journal, a complete analysis of literature published in Learning Organization may provide additional understanding of key developments and prospects.

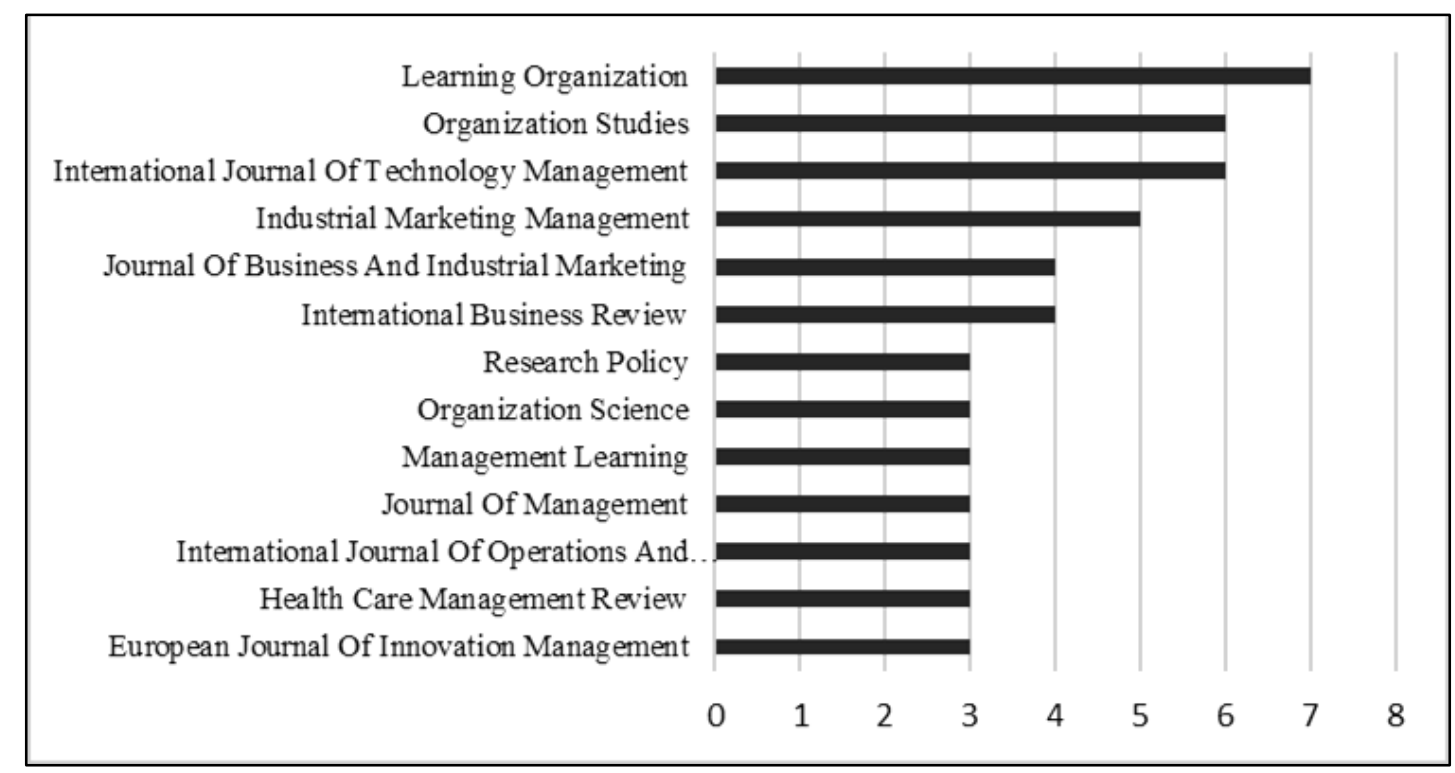

\section{Figure 10: Sample list of journals leading in number of publications in IOL studies}

The need for more exploratory research methods. In terms of research methods, we find that many of the papers on IOL adopt theoretical and conceptual approaches. When working with empirical data, both quantitative and qualitative research methods are well represented while mixed methods, as described by Hartley and Rashman (2018), is still not widely applied. If IOL is to be regarded as a learning process (Manuj et al. 2014), then this process must be explored through different methods. This entails that the process of IOL can be understood both in terms of variance models exploring the antecedents and consequences of IOL, the categories of concepts included in IOL and as a sequence of events that unfold during a change process (Van de Ven, 1992). More exploratory research methods can help researchers uncover aspects related to all three 
understandings of the IOL process. In particular, there is a need for real-time studies of IOL as it unfolds, as represented by Sienkiewicz-Małyjurek et al. (2019), rather than retrospective recounts that might favour the success stories (Alvesson and Sköldberg, 2009).

\subsection{Conclusion}

This paper makes central theoretical contributions by comprehensively reviewing the IOL literature through a unique combination of various bibliometric techniques. In doing so, we identify future research directions and implications that affect the future research agenda in IOL. Although scholarly interest in IOL has been increasing, it is still a nascent domain that has not been comprehensively addressed. This paper is the first to attempt in providing a comprehensive overview of IOL literature. Our analysis involved a literature review that not only mapped the field by identifying the leading authors, publications, countries, citations and publication growth, but also went further by examining the foundations and trends of the field. In this paper, we demonstrate how Scopus metrics and bibliometric methods can be used to synthesise literature through novel quantitative and structural indicators, and through qualitative synthesis methods. Furthermore, we use a comparatively more explicit and transparent methodology, which could help early-stage researchers and doctoral students to perform proper systematic reviews in the future. This is critical as being transparent about judgment calls and decisions in the theory, design, measurement, analysis and reporting of results is essential in high-quality research (Aguinis et al. 2018).

\subsection{Limitations}

Although this paper contributes to the growing corpus of IOL literature, there are a few limitations that need to be acknowledged. First, based on the cut off points set; the synthesis of literature may be limited. Our research is mainly based on papers published between 2009-2019, which may 
increase the bias. Furthermore, when investigating the evolution of IOL, we could have overlooked a number of seminal papers by restricting our analysis to the top ten most cited/co-cited papers. Furthermore, while conducting co-citation analysis, the bibliometric dataset was 'cleaned' manually by the authors, which may have resulted in some variance in citations used for study. Although we justify the use of Scopus as the main database, the scope of this research may be limited; therefore, data collected from Google Scholar, Web of Science, EBSCO, for example, may provide opportunities for future research. Lastly, we do not include conference papers and book chapters in our review, which could also be a probable limitation. 


\section{Appendix - A}

\begin{tabular}{|c|c|c|}
\hline Reference & Concept & Definition and/or example \\
\hline \multirow[t]{2}{*}{$\begin{array}{l}\text { Levitt and } \\
\text { March (1988) }\end{array}$} & $\begin{array}{l}\text { Learning } \\
\text { organization }\end{array}$ & $\begin{array}{l}\text { "Organizations are seen as learning by encoding inferences from } \\
\text { history into routines that guide behavior." (p.320) }\end{array}$ \\
\hline & $\begin{array}{l}\text { Organizational } \\
\text { learning }\end{array}$ & A routine-based, history-dependent and target-oriented process \\
\hline $\begin{array}{l}\text { Cohen and } \\
\text { Levinthal } \\
\text { (1990) }\end{array}$ & $\begin{array}{l}\text { Organizational } \\
\text { learning }\end{array}$ & $\begin{array}{l}\text { [rather, source of a firm's technical knowledge] "...exploitation } \\
\text { of competitors' research findings is realized through the } \\
\text { interaction of the firm's absorptive capacity with competitors' } \\
\text { spillovers." }\end{array}$ \\
\hline $\begin{array}{l}\text { Levinson and } \\
\text { Asahi (1995) }\end{array}$ & $\begin{array}{l}\text { Organizational } \\
\text { learning }\end{array}$ & $\begin{array}{l}\text { "...involves a single organization becoming aware of an intended } \\
\text { action and intended outcome, usually in another organization; it } \\
\text { traces how this organization adjusts its behavior to achieve the } \\
\text { outcome. [first-order organizational learning] ... Second-order } \\
\text { organizational learning requires not only the observation through } \\
\text { knowledge transfer but also the reflection on what is actually } \\
\text { occurring." (p. } 60-61 \text { ) }\end{array}$ \\
\hline $\begin{array}{l}\text { Powell et al. } \\
\text { (1996) }\end{array}$ & $\begin{array}{l}\text { Organizational } \\
\text { learning }\end{array}$ & $\begin{array}{l}\text { "Organizational learning is both a function of access to } \\
\text { knowledge and the capabilities for utilizing and building on such } \\
\text { knowledge." (p.118) }\end{array}$ \\
\hline $\begin{array}{l}\text { Lane and } \\
\text { Lubatkin } \\
\text { (1998) }\end{array}$ & $\begin{array}{l}\text { Inter- } \\
\text { Organizational } \\
\text { learning }\end{array}$ & $\begin{array}{l}\text { IOL defined through AC (with a shift from the firm to the } \\
\text { 'student-teacher' pairing): firms' ability to value ('know-what' } \\
\text { portion of the alliance partners' knowledge bases), assimilate } \\
\text { ('know-how'), and utilize ('know-why') new external knowledge } \\
\text { (steps of IOL). Here, a firm has an equal capacity to learn from } \\
\text { other organizations. IOL as a form of interactive learning between } \\
\text { two firms (unlike passive or active learning, where the knowledge } \\
\text { is usually articulable, i.e. no longer VRIN) }\end{array}$ \\
\hline
\end{tabular}




\subsection{References}

Aguinis, H. Ramani, R. \& Alabduljader, N. (2018). What You See is What You Get? Enhancing Methodological Transparency in Management Research. Academy of Management Annals, Vol. 12 No.1, pp.1-28

Alvesson, M. \& Skoldberg, K. (2009), "Positivism, social constructionism, critical realism: Three reference points in the philosophy of science", Reflexive methodology: New vistas for qualitative research, 15-52.

Ameli, P. \& Kayes, D.C. (2011), "Triple-loop learning in a cross-sector partnership: The DC central kitchen partnership", The Learning Organization, Vol. 18 No. 3, pp. 175-188.

Andrade, L. Hidalgo, C. \& Ther-Rios, F. (2019), "Social networks analysis in a socio-ecological estuarine system of Southern Chile $\left(41,6^{\circ} \mathrm{S}\right)$ : Diagnosis and contributions for the improvement of governance in riparian contexts", Desenvolvimento e Meio Ambiente, Vol. 50, pp.151-169.

Andreou, P.C. Louca, C. \& Petrou, A.P. (2016), "Organizational learning and corporate diversification performance”, Journal of Business Research, Vol 69. No 9, pp. 3270-3284.

Apriliyanti, I.D. \& Alon, I. (2017), "Bibliometric analysis of absorptive capacity", International Business Review, Vol 26. No. 5, pp. 896-907.

Bailón-Moreno, R. Jurado-Alameda, E. \& Ruiz-Baños, R. (2006), “The scientific network of surfactants: structural analysis", Journal of the American Society for Information Science and Technology, Vol. 57 No. 7, pp. 949-960.

Baraba'si, A.L., Jeong, H., Ne’da, Z., Ravasz, E., Schubert, A. and Vicsek, T. (2002), "Evolution of the social network of scientific collaborations", Physica A: Statistical Mechanics and Its Applications, North-Holland, Vol. 311 Nos 3/4, pp. 590-614

Baum, J.A. \& Ingram, P. (1998), "Survival-enhancing learning in the Manhattan hotel industry 1898-1980”, Management Science, Vol. 44 No. 7, Pp. 996-1016.

Belussi, F. Orsi, L. \& Savarese, M. (2019), “Mapping Business Model Research: A Document Bibliometric Analysis", Scandinavian Journal of Management, Vol. 35 No. 3, pp. 101048.

Benavides Espinosa, M.M. (2011), "Knowledge as a strategic resource for interorganizational learning", [El conocimiento como recurso estratégico para el aprendizaje interorganizativo] Revista Venezolana De Gerencia, Vol. 16 No. 56, pp. 563-577. 
Benckendorff, P. \& Zehrer, A. (2013), “A network analysis of tourism research”, Annals of Tourism Research, 43, 121-149.

Bendig, D. Enke, S. Thieme, N. \& Brettel, M. (2018), "Performance implications of crossfunctional coopetition in new product development: the mediating role of organizational learning”, Industrial Marketing Management, Vol. 73, pp. 137-153.

Borner, K., Chen, C. and Boyack, K.W. (2003), "Visualizing knowledge domains", Annual Review of Information Science and Technology, Vol. 37 No. 1, pp. 179-255

Bouncken, R. \& Barwinski, R. (2020), "Shared Digital Identity and Rich Knowledge Ties in Global 3D Printing-A Drizzle in the Clouds?”, Global Strategy Journal (in press).

Bouncken, R.B. Pesch, R. \& Kraus, S. (2015), "SME innovativeness in buyer-seller alliances: effects of entry timing strategies and inter-organizational learning", Review of Managerial Science, Vol. 9 No. 2, pp. 361-384.

Bouncken, R.B. Plüschke, B.D. Pesch, R. \& Kraus, S. (2016), "Entrepreneurial orientation in vertical alliances: Joint product innovation and learning from allies", Review of Managerial Science, Vol 10 No. 2, pp.381-409.

Brix, J. (2019), "Ambidexterity and organizational learning: Revisiting and reconnecting the literatures", The Learning Organization, Vol. 26 No. 4, pp.337-351.

Broekel, T. Balland, P. Burger, M. \& van Oort, F. (2014) "Modeling knowledge networks in economic geography: A discussion of four methods", Annals of Regional Science, Vol. 53 No. 2, pp.423-452.

Camps, J. Oltra, V. Aldás-Manzano, J. Buenaventura-Vera, G. \& Torres-Carballo, F. (2016), "Individual performance in turbulent environments: The role of organizational learning capability and employee flexibility", Human Resource Management, Vol. 55 No. 3, pp.363-383.

Cancino, C.A. Merigó, J.M. \& Coronado, F.C. (2017), “A bibliometric analysis of leading universities in innovation research.”, Journal of Innovation and Knowledge, Vol. 2 No. 3, pp.106-124.

Castrillon, M.A.G. Fischer, A.L. \& Nakata, L. (2012), “Organizational learning in Latin America: A descriptive study in Brazil and Colombia", [Aprendizagem organizacional na América Latina: Estudo descritivo no Brasil e Colômbia] Espacios, Vol. 33, No. 3, pp.3. 
Cerchione, R. \& Esposito, E. (2017), "Using knowledge management systems: A taxonomy of SME strategies", International Journal of Information Management, Vol. 37 No. 1, pp.1551-1562.

Chatenier, E.D. Verstegen, J.A.A.M. Biemans, H.J.A. Mulder, M. \& Omta, O. (2009), "The challenges of collaborative knowledge creation in open innovation teams", Human Resource Development Review, Vol. 8 No. 3, pp.350-381.

Chen, G. \& Xiao, L. (2016), “Selecting publication keywords for domain analysis in bibliometrics: A comparison of three methods", Journal of Informetrics, Vol. 10 No. 1, pp. 212-223.

Cheung, M.S. Myers, M.B. \& Mentzer, J.T. (2010), “Does relationship learning lead to relationship value? A cross-national supply chain investigation", Journal of Operations Management, Vol. 28, No. 6, pp.472-487.

Choi, K. Jean, R. -. B. \& Kim, D. (2019), "The impacts of organizational learning capacities on relationship-specific innovations: Evidence from the global buyer-supplier relationship", International Marketing Review, Vol 36 No. 6, pp.1042-1066.

Cobo, M.J. López-Herrera, A.G. Herrera-Viedma, E. \& Herrera, F. (2011), "Science mapping software tools: Review, analysis, and cooperative study among tools", Journal of the American Society for Information Science and Technology, Vol. 62 No. 7, pp.1382-1402.

Cohen, W.M. \& Levinthal, D.A. (1990), “Absorptive capacity: A new perspective on learning and innovation", Administrative Science Quarterly, Vol. 35 No. 1, pp.128-152.

Connaway, L.S. \& Powell, R.R. (2010), “Basic research methods for librarians (5th-edition)”, California, USA: Libraries Unlimited Publishers.

Crossan, M. M., Lane, H. W., \& White, R. E. (1999). An organizational learning framework: From intuition to institution. Academy of management review, Vol.24 No3, pp.522-537.

Denyer, D. \& Tranfield, D. (2006), "Using qualitative research synthesis to build an actionable knowledge base", Management Decision, Vol. 44 No. 2, pp.213-227.

Durieux, V. and Gevenois, P.A. (2010), "Bibliometric indicators: quality measurements of scientific publication”, Radiology, Radiological Society of North America, Vol. 255 No. 2, pp. 342-351.

Easterby-Smith, M. Lyles, M.A. \& Tsang, E.W.K. (2008), "Inter-organizational knowledge transfer: current themes and future prospects", Journal of Management Studies, Vol. 41 No. 1, pp.677-690. 
Eiriz, V. Gonçalves, M. \& Areias, J.S. (2017), “Inter-organizational learning within an institutional knowledge network: A case study in the textile and clothing industry", European Journal of Innovation Management, Vol. 20 No. 2, pp.230-249.

Engeström, Y. \& Kerosuo, H. (2007), "From workplace learning to inter-organizational learning and back: the contribution of activity theory", Journal of Workplace Learning, Vol. 19 No. 6, pp.336-342.

Fang, S. Tsai, F. \& Lin, J. L. (2010), “Leveraging tenant-incubator social capital for organizational learning and performance in incubation programme", International Small Business Journal, Vol. 28 No. 1, pp.90-113.

Feller, J. Parhankangas, A. Smeds, R. \& Jaatinen, M. (2013), "How companies learn to collaborate: Emergence of improved inter-organizational processes in R\&D alliances", Organization Studies, Vol. 34 No. 3, pp.313-343.

Fredrich, V. Bouncken, R.B. \& Kraus, S. (2019), “The race is on: Configurations of absorptive capacity, interdependence and slack resources for interorganizational learning in coopetition alliances", Journal of Business Research, Vol. 101, pp. 862-868.

Galvagno, M. (2017). Bibliometric literature review: An opportunity for marketing scholars. Mercati \& Competitività. Vol.2017, No. 4

Garg, K.C. \& Tripathi, H.K. (2017), "Bibliometrics and Scientometrics in India: An overview of studies during 1995-2014 Part I: Indian publication output and its citation impact", Annals of Library and Information Studies, Vol. 64 No. 1, pp.28-36

Gasparyan, A. Y., Yessirkepov, M., Duisenova, A., Trukhachev, V. I., Kostyukova, E. I., \& Kitas, G. D. (2018). Researcher and author impact metrics: variety, value, and context. Journal of Korean medical science, Vol. 33 No. 18.

Gaviria-Marin, M. Merigó, J. M. \& Baier-Fuentes, H. (2018), “Twenty years of the Journal of Knowledge Management: A bibliometric analysis”, Journal of Knowledge Management, Vol. 22 No. 8, pp.1655-1687.

Gaviria-Marin, M., Merigó, J. M., \& Baier-Fuentes, H. (2019). Knowledge management: A global examination based on bibliometric analysis. Technological Forecasting and Social Change, Vol. 140 pp.194-220

Gibb, J. Sune, A. \& Albers, S. (2017), 'Network learning: Episodes of interorganizational learning towards a collective performance goal”, European Management Journal, Vol 35, No. 1, pp.15-25. 
Gurzki, H. \& Woisetschläger, D. M. (2017), "Mapping the luxury research landscape: A bibliometric citation analysis", Journal of Business Research, Vol. 77, pp.147-166.

Halachmi, A. \& Woron, A.M. (2013), "Spontaneous inter-organizational learnin”, International Journal of Organization Theory and Behavior, Vol. 16 ,No. 2, pp.135-164.

Hallikas, J. Kärkkäinen, H. \& Lampela, H. (2009), "Learning in networks: An exploration from innovation perspective", International Journal of Technology Management, Vol. 45 No. 3-4, pp.229-243.

Hamel, G. (1991), “Competition for competence and interpartner learning within international strategic alliances”, Strategic Management Journal, Vol.12, No. S1, pp.83-103.

Hao, B. \& Feng, Y. (2018), 'Leveraging learning forces in asymmetric alliances: Small firms' perceived power imbalance in driving exploration and exploitation", Technovation, Vol. 78, pp.27-39.

Hartley, J. \& Rashman, L. (2018). "Innovation and inter-organizational learning in the context of public service reform", International Review of Administrative Sciences, Vol. 84t, No. 2, pp.231-248.

Harzing, A.W. \& Alakangas, S. (2016), "Google Scholar, Scopus and the Web of Science: a longitudinal and cross-disciplinary comparison”, Scientometrics, Vol. 106, No. 2, pp.787804.

Hernández-Espallardo, M. Rodríguez-Orejuela, A. \& Sánchez-Pérez, M. (2010), “Interorganizational governance, learning and performance in supply chains", Supply Chain Management, Vol. 15 No. 2, pp.101-114.

Holmqvist, M. (2003), "Intra and interorganisational learning processes: An empirical comparison", Scandinavian Journal of Management, Vol. 19, No. 4, pp.443-466.

Holmqvist, M. (2004), "Experiential learning processes of exploitation and exploration within and between organizations: An empirical study of product development", Organization Science, Vol. 15, No. 1, pp.70-81.

Holmqvist, M. (2009), "Complicating the organization: A new prescription for the learning organization?”, Management Learning, Vol. 40, No. 3, pp.275-287.

Huang, M.H. (2012), "Exploring the h-index at the institutional level: A practical application in world university rankings", Online Information Review, Vol. 36 No. 4, pp.534-547. 
Huang, Y.-T. \& Chu, W. (2010), "Enhancement of product development capabilities of OEM suppliers: inter- and intra- organizational learning”, Journal of Business and Industrial Marketing, Vol. 25, No. 2, pp.147-158.

Huber, G.P. (1991), “Organizational learning: The contributing processes and the literatures", Organization Science, Vol 2 No. 1, pp.88-115.

James, C., Colledge, L., Meester, W., Azoulay, N., \& Plume, A. (2018). CiteScore metrics: Creating journal metrics from the Scopus citation index. Learned Publishing. Vol 32. No.4 pp.367-374

Jiang, Y. Ritchie, B.W. and Benckendorff, P. (2019). Bibliometric visualisation: An application in tourism crisis and disaster management research. Current Issues in Tourism, 22(16), pp.1925-1957. Kim, G.M. (2016). Collaborative innovation with suppliers in a turbulent market. Asian Journal of Technology Innovation, Vol. 24 No. 2, pp.179-201.

Knight, L. (2002), "Network learning: Exploring learning by interorganizational networks", Human Relations, Vol. 55 No. 4, pp.427-454.

Kohtamäki, M. \& Partanen, J. (2016), “Co-creating value from knowledge-intensive business services in manufacturing firms: The moderating role of relationship learning in suppliercustomer interactions”, Journal of Business Research, Vol. 69 No. 7, pp.2498-2506.

Kolle, S.R. Shankarappa, T.H. Arun, M. \& Manjunatha Reddy, T.B. (2017), “Characteristics and trends in global lead removal research: A science citation index expanded-based analysis", Desalination and Water Treatment, Vol. 80, pp.164-173.

Kolle, S.R. Shankarappa, T.H. Manjunatha Reddy, T.B. \& Muniyappa, A. (2015), "Scholarly communication in the international journal of pest management: a bibliometric analysis from 2005 to 2014", Journal of Agricultural and Food Information, Vol. 16, No. 4, pp.301-314

Koseoglu, M.A. (2016), "Growth and structure of authorship and co-authorship network in the strategic management realm: Evidence from the Strategic Management Journal”. Business Research Quarterly, Vol. 19 No. 3, pp.153-170

Lane, P.J. \& Lubatkin, M. (1998), "Relative absorptive capacity and interorganizational learning”, Strategic Management Journal, Vol. 19 No. 5, pp.461-477.

Larsson, R. Bengtsson, L. Henriksson, K. \& Sparks, J. (1998), "The interorganizational learning dilemma: Collective knowledge development in strategic alliances", Organization Science, Vol. 9 No. 3, pp.285-305. 
Leung, A. Xu, H. Wu, G.J. \& Luthans, K.W. (2019), "Industry peer networks (IPNs): Cooperative and competitive interorganizational learning and network outcomes", Management Research Review, Vol. 42 No. 1, pp.122-140.

Levinson, N.S. \& Asahi, M. (1995), “Cross-national alliances and interorganizational learning”, Organizational Dynamics, Vol. 24 No. 2, pp.50-63.

Levitt, B. \& March, J.G. (1988), “Organizational learning”, Annual Review of Sociology, Vol. 14 No. 1, pp.319-338.

Liao, H., Tang, M., Luo, L., Li, C., Chiclana, F. and Zeng, X.J. (2018). A bibliometric analysis and visualization of medical big data research. Sustainability, Vol 10 No.1, pp. 166

Liu, C.-L.E. (2012), “An investigation of relationship learning in cross-border buyer-supplier relationships: the role of trust”, International Business Review, Vol. 21 No. 3, pp.311-327.

López-Illescas, C. de Moya Anegón, F. \& Moed, H.F. (2009), “Comparing bibliometric countryby-country rankings derived from the Web of Science and Scopus: the effect of poorly cited journals in oncology", Journal of Information Science, Vol. 35 No. 2, pp.244-256.

Manuj, I. Omar, A. \& Pohlen, T.L. (2014), “Inter-organizational learning in supply chains: A focus on logistics service providers and their customers", Journal of Business Logistics, Vol. 35 No. 2, pp.103-120.

Manuj, I. Omar, A. \& Yazdanparast, A. (2013), "The quest for competitive advantage in global supply chains: The role of interorganizational learning”, Transportation Journal, Vol. 52 No.4, pp.463-492.

March, J.G. (1991), "Exploration and exploitation in organizational learning”, Organization Science, Vol 2 No. 1, pp.71-87.

Mariani, M. and Borghi, M., 2019. Industry 4.0: A bibliometric review of its managerial intellectual structure and potential evolution in the service industries. Technological Forecasting and Social Change, 149, p.119752.

Mariotti, F. (2012), "Exploring interorganizational learning: A review of the literature and future directions", Knowledge and Process Management, Vol. 19 No. 4, pp.215-221.

Martínez-Noya, A. \& García-Canal, E. (2016), "The framing of knowledge transfers to shared R\&D suppliers and its impact on innovation performance- A regulatory focus perspective", R\&D Management, Vol. 46 No. 2, pp.354-368. 
Massaro, M. Dumay, J. \& Guthrie, J. (2016), “On the shoulders of giants: undertaking a structured literature review in accounting", Accounting, Auditing and Accountability Journal, Vol. 29 No. 5, pp.767-801.

Melo, S. \& Beck, M. (2015), "Intra and interorganizational learning networks and the implementation of quality improvement initiatives: The case of a Portuguese teaching hospital”, Human Resource Development Quarterly, Vol. 26 No. 2, pp.155-183.

Mering, M. (2017). Bibliometrics: understanding author-, article-and journal-level metrics. Serials Review, Vol 43. No 1, pp.41-45.

Morrison, A. Lynch, P. \& Johns, N. (2004), "International tourism networks", International Journal of Contemporary Hospitality Management, Vol. 16 No. 3, pp.197-202.

Mozzato, A.R. Bitencourt, C.C. \& Grzybovski, D. (2015), "The interorganizational level in the learning continuum: Analytic conceptual scheme”, International Business Research, Vol. 8 No. 4, pp.94-106.

Mutiganda, J. C. (2016), "Financial management of public services in a hybrid organisation: A learning approach in inter-organisational settings", International Journal of Public Sector Performance Management, Vol. 2 No. 4, pp.310-330.

Nonaka, I. (1994), “A dynamic theory of organizational knowledge creation”, Organization Science, Vol. 5 No. 1, pp.14-37.

Otto, P. (2012), "Dynamics in strategic alliances: A theory on interorganizational learning and knowledge development", International Journal of Information Technologies and Systems Approach, Vol. 5 No. 1, pp.74-86.

Peronard, J. \& Brix, J. (2019), “Organizing for inter-organizational learning in service networks", The Learning Organization, Vol. 26 No. 3, pp.276-288.

Pesta, B. Fuerst, J. \& Kirkegaard, E.O.W. (2018), "Bibliometric Keyword Analysis across Seventeen Years (2000 - 2016) of Intelligence Publications”, Journal of Intelligence, Vol. 46 No. 6, pp.1-12.

Popova-Nowak, I.V. \& Cseh, M. (2015), "The Meaning of Organizational Learning: A MetaParadigm Perspective", Human Resource Development Review, Vol. 14 No. 3, pp.299331.

Portugal Ferreira, M. (2011), “A bibliometric study on Ghoshal's managing across borders", Multinational Business Review, Vol. 19 No. 4, pp.357-375. 
Powell, W.W. Koput, K.W. \& Smith-Doerr, L. (1996), "Interorganizational collaboration and the locus of innovation: Networks of learning in biotechnology", Administrative Science Quarterly, pp. 116-145.

Raghuram, S. Tuertscher, P. \& Garud, R. (2010), "Research note-mapping the field of virtual work: A co-citation analysis”, Information Systems Research, Vol. 21 No. 4, pp.983-999.

Raj, R. \& Srivastava, K.B. (2016), "Mediating role of organizational learning on the relationship between market orientation and innovativeness", The Learning Organization, Vol. 23 No. 5, pp.370-384.

Rajala, A. (2018), "Examining the effects of interorganizational learning on performance: a metaanalysis", Journal of Business and Industrial Marketing, Vol. 4(January), pp. 574-584.

Renaud, A. Walsh, I. \& Kalika, M. (2016), "Is SAM still alive? A bibliometric and interpretive mapping of the strategic alignment research field", The Journal of Strategic Information Systems, Vol. 25 No. 2, pp.75-103.

Ring, P.S. \& Van de Ven, A.H. (1994), "Developmental processes of cooperative interorganizational relationships", Academy of Management Review, Vol. 19 No. 1, pp. 90-118.

Ruel, S. Evrard-Samuel, K. \& Vignard, N. (2013), "Collaboration and information sharing in an internal supply chain during an innovation project”, Supply Chain Forum, Vol. 14 No. 4, pp.32-41.

Salager-Meyer, F. (1990), "Discoursal flaws in medical English abstracts: A genre analysis per research-and text-type”. Text-Interdisciplinary journal for the study of discourse, Vol. 10 No. 4, pp.365-384.

Salmi, P. \& Torkkeli, M.T. (2010), "Comparing the antecedents of absorptive capacity in exploitation and exploration alliances: The case of a software company", International Journal of Business Excellence, Vol. 3 No. 4, pp.452-469.

Schick-Makaroff, K. MacDonald, M. Plummer, M. Burgess, J. \& Neander, W. (2016), "What Synthesis Methodology Should I Use? A Review and Analysis of Approaches to Research Synthesis", AIMS Public Health, Vol. 3 No. 1, pp.172-215.

Schildt, H. Keil, T. \& Maula, M. (2012), "The temporal effects of relative and firm-level absorptive capacity on interorganizational learning”, Strategic Management Journal, Vol. 33 No 10, pp.1154-1173. 
Schildt, H.A. Maula, M.V. \& Keil, T. (2005), "Explorative and exploitative learning from external corporate ventures", Entrepreneurship Theory and Practice, Vol. 29 No. 4, pp. 493-515.

Schilke, O. \& Goerzen, A. (2010), "Alliance management capability: an investigation of the construct and its measurement”, Journal of Management, Vol. 36 No. 5, pp.1192-1219.

Scott, J. E. (2000), "Facilitating interorganizational learning with information technology", Journal of Management Information Systems, Vol. 17 No. 2, pp.81-113.

Sedighi, M. \& Jalalimanesh, A. (2014), "Mapping research trends in the field of knowledge management", Malaysian Journal of Library and Information Science, Vol. 19 No. 1, pp.71-85.

Serenko, A. \& Dumay, J. (2015), "Citation classics published in KM journals. Part II: studying research trends and discovering the Google Scholar Effect”, Journal of Knowledge Management, Vol. 19 No. 6, pp.1335-1355.

Sheng, M.L. \& Chien, I. (2016), "Rethinking organizational learning orientation on radical and incremental innovation in high-tech firms" Journal of Business Research, Vol. 69 No. 6, pp. 2302-2308.

Sienkiewicz-Małyjurek, K.E. Kożuch, B. \& Szczygłowski, J. (2019), "Inter-organisational learning in public safety management system", Disaster Prevention and Management: An International Journal, Vol. 28, No.2, pp.286-298.

Smeds, R. \& Alvesalo, J. (2003), "Telepresence in cross-site business process simulation - lessons learnt in technology, social interaction and organizational learning”, Production Planning and Control, Vol. 14 No. 2, pp.182-192.

Snilstveit, B. Oliver, S. \& Vojtkova, M. (2012), "Narrative approaches to systematic review and synthesis of evidence for international development policy and practice", Journal of Development Effectiveness, Vol. 4 No. 3, pp.409-429.

Storbacka, K. \& Nenonen, S. (2015), “Learning with the market: Facilitating market innovation”. Industrial Marketing Management, Vol. 44, pp.73-82.

Surdu, I. Mellahi, K. Glaister, K.W. \& Nardella, G. (2018)”, Why wait? Organizational learning, institutional quality and the speed of foreign market re-entry after initial entry and exit", Journal of World Business, Vol. 53 No. 6, pp.911-929.

Swales, J.M. (1990). Genre analysis: English in academic and research settings. Cambridge: Cambridge University Press. 
Thomas, J. Harden, A. \& Newman, M. (2012), “Synthesis: combining results systematically and appropriately", In D. Gough, S. Oliver, and J. Thomas, An introduction to systematic reviews, pp. 179-226. London: Sage.

Thyer, B. A. (2008), "Preparing Research Publications. Social Work Research Methods”, Oxford University Press.

Tolsby, J. (2018), “Organizational learning as participants' knowledge harvesting from product development”, The Learning Organization, Vol. 25 No. 6, pp.422-433.

Torchia, M. \& Calabrò, A. (2019), “Open Innovation in SMEs: A Systematic Literature Review”, Journal of Enterprising Culture, Vol. 27 No. 2, pp.201-228.

Tran, C. \& Aytac S. (2016), "Evidence Based Library and Information Practice", Library and Information Practice, Vol. 11, pp.16-33.

Tranfield, D. Denyer, D. \& Smart, P. (2003), “Towards a methodology for developing evidenceinformed management knowledge by means of systematic review", British Journal of Management, Vol. 14 No 3, pp.207-222.

Van de Ven, A.H. (1992), "Suggestions for studying strategy process: A research note”, Strategic Management Journal, Vol. 13 No. S1, pp.169-188.

Van Eck, N.J. \& Waltman, L. (2010). Software survey: Vosviewer, a computer program for bibliometric mapping. Scientometrics, 84(2), 523-538.

Vasudeva, G. Alexander, E.A. \& Jones, S.L. (2015), "Institutional logics and interorganizational learning in technological arenas: Evidence from standard-setting organizations in the mobile handset industry", Organization Science, Vol. 26 No. 3, pp.830-846.

Vecchiato, R. (2017), "Disruptive innovation, managerial cognition, and technology competition outcomes", Technological Forecasting and Social Change, Vol. 116, pp.116-128.

Vesalainen, J. Thorgren, S. \& Rossi, T. (2017), “Toward cross-border engineering management: Development and test of a practice for idea generation in Customer-Supplier DFM teams”, EMJ - Engineering Management Journal, Vol. 29 No. 4, pp.278-286.

Vogel, R. \& Güttel, W.H. (2013), “The dynamic capability view in strategic management: A bibliometric review", International Journal of Management Reviews, Vol. 15 No. 4, pp. 426-446.

Vogel, R. Hattke, F. \& Petersen, J. (2017), “Journal rankings in management and business studies: What rules do we play by?", Research Policy, Vol. 46 No. 10, pp. 1707-1722. 
Wadhwa, A. \& Basu, S. (2013), "Exploration and resource commitments in unequal partnerships: An examination of corporate venture capital investments", Journal of Product Innovation Management, Vol. 30 No. 5, pp. 916-936.

Walsh, I. \& Renaud, A. (2017), "Reviewing the literature in the IS field: Two bibliometric techniques to guide readings and help the interpretation of the literature", Systèmes d'Information and Management, Vol. 22 No.3, pp.75-115.

Walter, C. \& Ribière, V. (2013), "A citation and co-citation analysis of 10 years of KM theory and practices", Knowledge Management Research and Practice, Vol 11 No. 3, pp. 221-229.

Wegner, D. \& Mozzato, A. R, (2019), "Shall we cooperate, or shall we compete? How network learning episodes influence strategic decisions in strategic networks", International Journal of Management and Enterprise Development, Vol. 18 No 3, pp.171-188.

Zhu, Q. Krikke, H. \& Caniëls, M.C.J. (2018), “Supply chain integration: Value creation through managing inter-organizational learning”, International Journal of Operations and Production Management, Vol. 38 No.1, pp. 211-229.

Zupic, I. \& Čater, T. (2015), "Bibliometric Methods in Management and Organization", Organizational Research Methods, Vol.18 No 3, pp. 429-472. 